UNITED STATES DEPARTMENT OF THE INTERIOR

GEOLOGICAL SURVEY

\title{
Analytical results and sample locality map \\ of stream-sediment and heavy-mineral-concentrate samples \\ from the El Paso Mountains Wilderness Study Area (CDCA 164), \\ Inyo County, California
}

By

David E. Detra, Marjorie S. Erickson, Robert E. Tucker, Michael F. Diggles, and Nancy L. Parduhn

Open-File Report 84-571

This report is preliminary and has not been reviewed for conformity with U.S. Geological Survey editorial standards and stratigraphic nomenclature. Any use of trade names is for descriptive purposes only and does not imply endorsement by the USGS. 


\section{CONTENTS}

Studies related to wilderness................................ 1

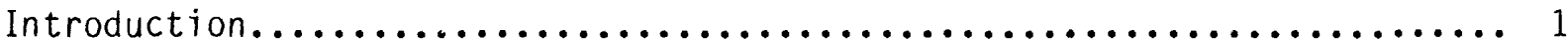

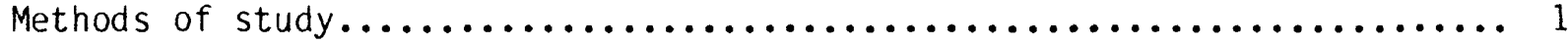

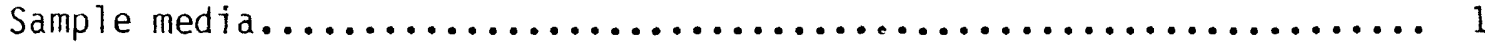

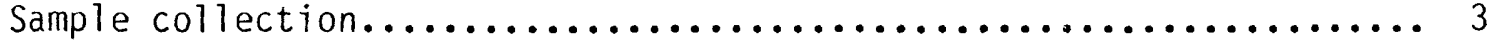

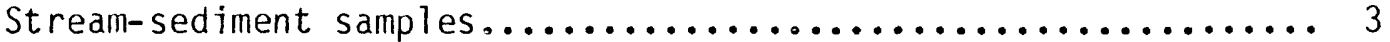

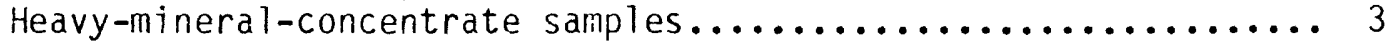

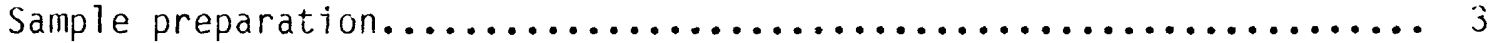

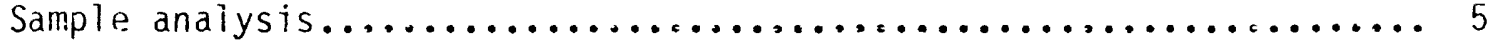

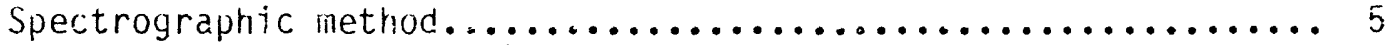

Rock Analysis Storage System (RASS) ......................... 5

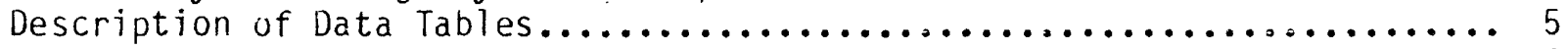

References cited....................................... 6

\section{ILUUSTRATIONS}

FIGURE 1. Location map of the EI Paso Mountains Wilderness

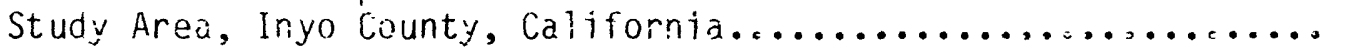

FIGURE 2. Sampling sites in the El Paso Mountains wilderress

Study Area, Inyo Courity, California.....................

\section{TABLES}

TABLE 1. Limits of determination for spectrographic analysis of

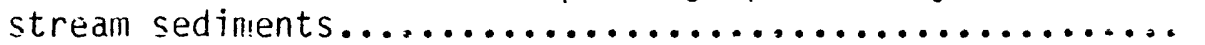

TABLE 2. Anaiytical resuits from the minus-80-mesh streamsediment samples from the El Paso Mountains

wilderness Study Area, California.................

TABLE 3. Analytical results from the nonniagnetic-heavymineral-concentrate samples from the El Paso Mountains Wilderness Study Area, California............ 10 


\section{STUDIES RELATED TO WILDERNESS}

\section{Bureau of Land Management Wilderness Study Areas}

The Federal Land Policy and Management Act (Public Law 94-579, October 21,1976 ) requires the U.S. Geological Survey and the U.S. Bureau of Mines to conduct mineral surveys on certain areas to determine their mineral values, if any. Results must be made available to the public and be submitted to the President and the Congress. This report presents the results of a mineral survey of the El Paso Mountains Wilderness Study Area, California Desert Conservation Area, Inyo County, California.

\section{INTRODUCTION}

In the spring 1982 the U.S. Geological Survey conducted a reconnaissance geochemical survey of the El Paso Mountains Wilderness Study Area, Inyo County, California.

The El Paso Mountains Wilderness Study Area comprises about $25 \mathrm{mi}^{2}$ (65 $\mathrm{km}^{2}$ ) in southeastern California, and lies about $15 \mathrm{mi}(24 \mathrm{~km})$ southwest of Ridgecrest (see fig. 1). Access to the study area is provided on the west by Highway 14, and on the east by Interstate 395 (fig. 1).

The El Paso Mountains are located in the Basin and Range Province just north of the Garlock fault. The study area consists of the northern and northwestern portion of the El Paso Mountains known as the Black Hills. The rocks in the area consist of claystone, siltstone, marlstone, arkosic sandstone, and conglomerate of the Goler Formation (Paleocene), which is overlain by ash-flow and airfall tuff, tuffaceous sandstone, andesite breccia, and minor conglomerate of the Ricardo Formation (Miocene), which is overlain by olivine basalt flows of the Black Mountain Basalt (Miocene), and dissected alluvial deposits, younger surficial deposits, and landslide deposits (Pleistocene and Holocene). The individual formations have been described in detail by Cox (1982) and Cox and Morton (1980).

The topographic relief in the study area is about $2200 \mathrm{ft}(670.5 \mathrm{~m})$, with a maximum elevation of $5244 \mathrm{ft}(1598 \mathrm{~m})$. The ground surface is mountainous grading into pediment veneers, stream-terrace deposits and alluvial fans. The climate is arid to semiarid.

\section{METHODS OF STUDY}

\section{Sample Media}

Analyses of the stream-sediment samples represent the chemistry of the rock material eroded from the drainage basin upstream from each sample site. Such information is useful in identifying those basins which contain concentrations of elements that may be related to mineral deposits. Heavy-mineral-concentrate samples provide information about the chemistry of a limited number of minerals in rock material eroded from the drainage basin upstream from each sample site. The selective concentration of minerals, many of which are ore-related, permits determination of some elements that are not easily detected in stream-sediment samples. 


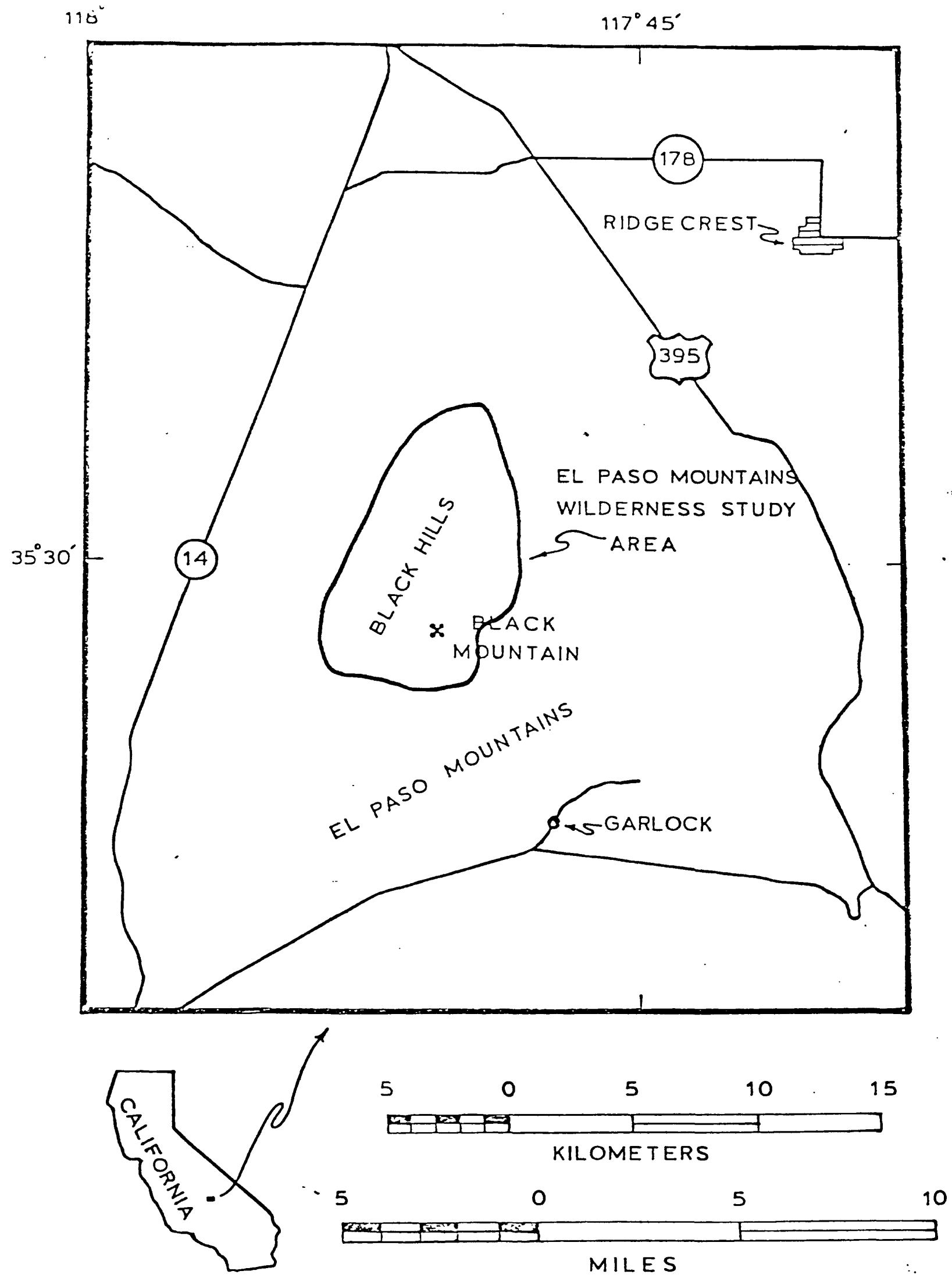

Figure 1.--Location map of the El Paso Mountains Wilderness Study Area, Inyo County, California 


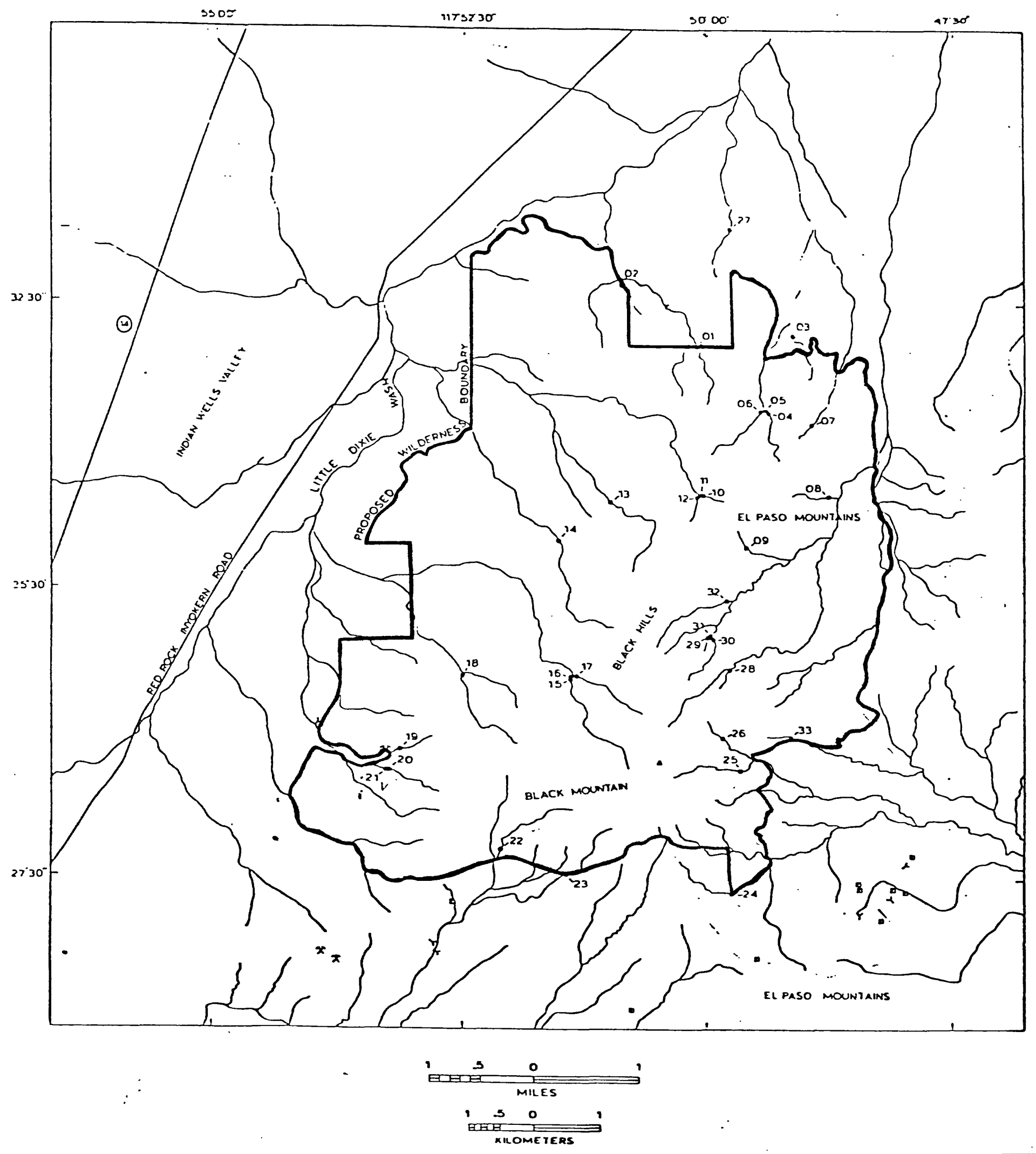

Figure 2. Sampling sites in the El Paso Mountains Wilderness Study Area, Inyo County, California. 


\section{Sample Analysis}

\section{Spectrographic method}

The stream-sediment, heavy-mineral-concentrate, and rock samples were analyzed for 31 elements using a semiquantitative, direct-current arc emission spectrographic method (Grimes and Marranzino, 1968). The elements analyzed and their lower limits of determination are 1isted in Table 1. Spectrographic results were obtained by visual comparison of spectra derived from the sample against spectra obtained from standards made from pure oxides and carbonates. Standard concentrations are geometrically spaced over any given order of magnitude of concentration as follows: 100,50,20,10, and so forth. Samples whose concentrations are estimated to fall between those values are assigned values of $70,30,15$, and so forth. The precision of the analytical method is approximately plus or minus one reporting interval at the 83 percent confidence level and plus or minus two reporting intervals at the 96 percent confidence level (Motooka and Grimes, 1976). Values determined for the major elements (iron, magnesium, calcium, and titanium) are given in weight percent; all others are given in parts per million (micrograms/gram). Analytical data for samples from the El Paso Mountains Wilderness Study Area are listed in Tables 2 and 3.

\section{ROCK ANALYSIS STORAGE SYSTEM}

Upon completion of all analytical work, the analytical results were entered into a computer-based file called Rock Analysis Storage System (RASS). This data base contains both descriptive geological information and analytical data. Any or all of this information may be retrieved and converted to a binary form (STATPAC) for computerized statistical analysis or publication (VanTrump and Miesch, 1976).

\section{DESCRIPTION OF DATA TABLES}

Tables 2 and 3 list the analyses for the samples of stream sediment and heavy-mineral concentrate, respectively. For the two tables, the data are arranged so that column 1 contains the USGS-assigned sample numbers. These numbers correspond to the numbers shown on the site location maps (plate 1). Columns in which the element headings show the letter "s" below the element symbol are emission spectrographic analyses; "aa" indicates atomic absorption analyses. A letter " $N$ " in the tables indicates that a given element was looked for but not detected at the lower limit of determination shown for that element in table 1. If an element was observed but was below the lowest reporting value, a "less than" symbol (<) was entered in the tables in front of the lower limit of determination. If an element was observed but was above the highest reporting value, a "greater than" symbol ( $>$ ) was entered in the tables in front of the upper limit of determination. If an element was not looked for in a sample, two dashes (--) are entered in tables 3-6 in place of an analytical value. Because of the formatting used in the computer program that produced tables 2 and 3, some of the elements listed in these tables (Fe, $\mathrm{Mg}, \mathrm{Ca}, \mathrm{Ti}, \mathrm{Ag}$, and $\mathrm{Be}$ ) carry one or more nonsignificant digits to the right of the significant digits. The analysts did not determine these elements to the accuracy suggested by the extra zeros. 
The spectrographic determinations for $\mathrm{Ag}, \mathrm{As}, \mathrm{Au}, \mathrm{Bi}, \mathrm{Cd}, \mathrm{Sn}, \mathrm{W}, \mathrm{Zn}$, and Th in stream-sediment samples, and for $\mathrm{As}, \mathrm{Au}, \mathrm{Bi}, \mathrm{Cd}, \mathrm{Sb}$, and $\mathrm{Zn}$ in heavymineral-concentrate samples, were all below the lower limits of determinations shown in table 1. Two samples contained less than 1 ppm Be concentrations (006 and 030) and one less than 5 ppm Mo value was reported in sample 023 in stream-sediment samples. In the heavy-mineral-concentrate data set all $\mathrm{Ti}$ values were reported as greater than $2 \%$. One sample contained $\mathrm{Ag}(010,1 \mathrm{ppm})$ and one $W$ value was reported $(025,<100 \mathrm{ppm})$. The columns for a11 elements listed above have been deleted from tables 3 and 4 .

\section{REFERENCES CITED}

Cox, B. F., 1982, Stratigraphy, sedimentology, and structure of the Goler Formation (Paleocene), El Paso Mountains, California: Implications for Paleocene tectonism on the Garlock Fault zone: Ph.D. thesis, University of California, Riverside, $248 \mathrm{p}$.

Cox, B. F., and Morton, J. L., 1980, Late Permian plutonism, El Paso Mountains, California [abs.]: Geological Society of America Abstracts with Programs, v. 12, no. 3, p. 103.

Grimes, D. J., and Marranzino, A. P., 1968, Direct-current arc and alternating-current spark emission spectrographic field methods for the semiquantitative analysis of geologic materials: U.S. Geological Survey Circular 591, $6 \mathrm{p}$.

Motooka, J. M., and Grimes, D. J., 1976, Analytical precision of one-sixth order semiquantitative spectrographic analyses: U.S. Geological Survey Circular 738, $25 \mathrm{p}$.

VanTrump, George, Jr., and Miesch, A. T., 1976, The U.S. Geological Survey RASS-STATPAC system for management and statistical reduction of geochemical data: Computers and Geosciences, v. 3, p. 475-488. 
TABLE 1.--Limits of determination for the spectrographic analysis of rocks and stream sediments, based on a $10-\mathrm{mg}$ sample

[The spectrographic limits of determination for heavy-mineral-concentrate samples are based on a 5-mg sample, and are therefore two reporting intervals higher than the limits given for rocks and stream sediments]

Elements Lower determination limit......Upper determination limit

Percent

\begin{tabular}{lcr}
\hline Iron (Fe) & 0.05 & 20 \\
Magnesium (Mg) & .02 & 10 \\
Calcium (Ca) & .05 & 20 \\
Titanium (Ti) & .002 & 1 \\
\hline
\end{tabular}

Parts per million

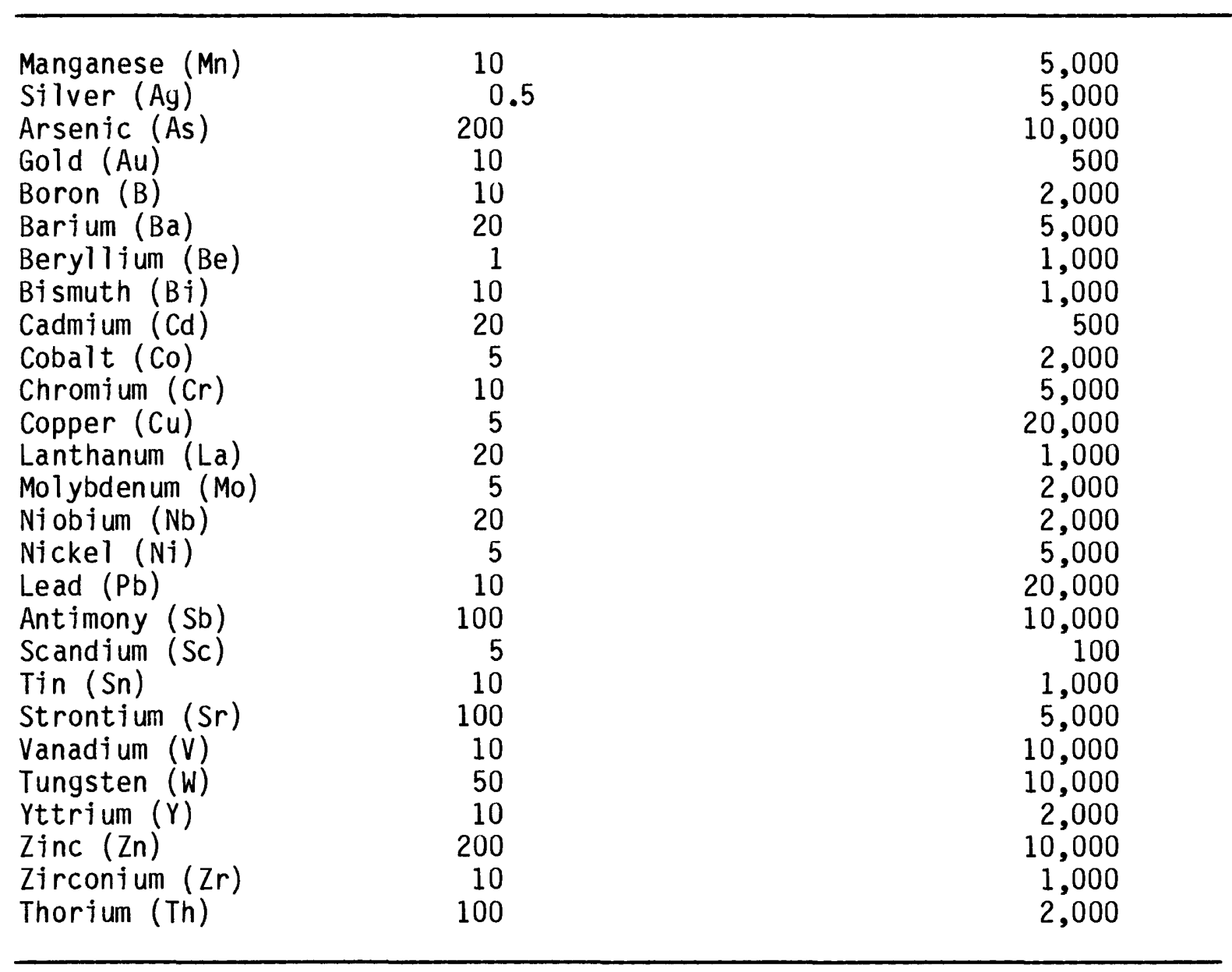




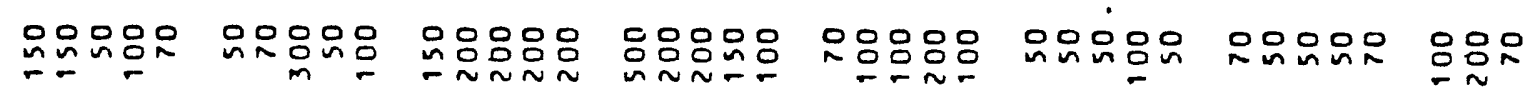

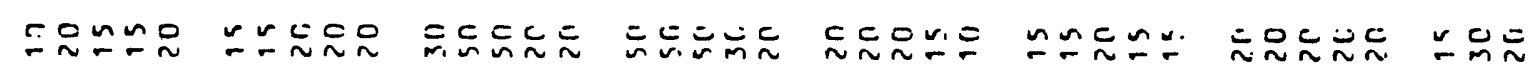

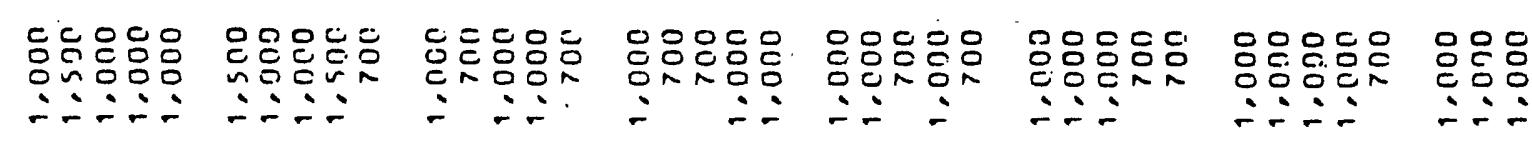

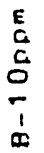

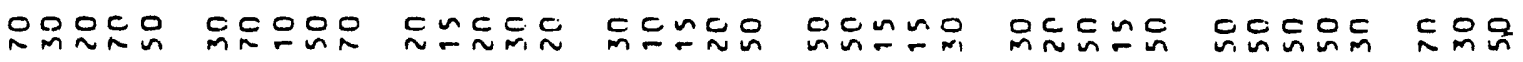

म

동은동응영 응등음윰등

은음읃음

등등등응

$\therefore \therefore$

$\therefore \because \because \div$

$\therefore$ i $\dot{i}$

流的

등웅등음

$\because \because:$

은등웅은응

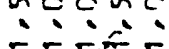

응응응등 등음

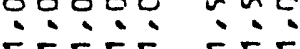

$\frac{2}{n}$

范

है $\backsim$

$\infty$ \&

宅

0.5000 0.50.0

0000

O다은

cooco

cocen

NCOOC

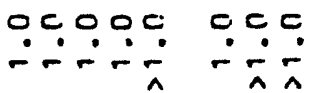

E:

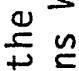

i.

ह

ociog ecince

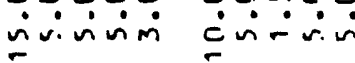

c오다.

c: cicoc

90000

00000

cocc. o. 으. r

\section{c.ño}

ccic:ca

c.uc.c.s

c.0.0.

c.c.c. $c$ :

m.ncen

c.c.c. c. . .

$\because$ 든ㄷㅇㅇ

gnะก

Ennก $\approx$

orona z-nuo oun

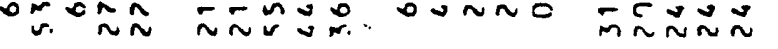

$\stackrel{\sim}{a \sim ⿻ 上 丨}$

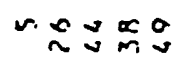

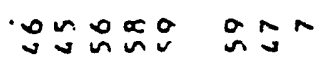

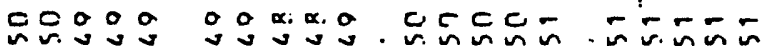

$\sim$ m.m.mm

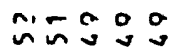

00000000

nNan

กNกล

$\sim \sim \sim \sim \sim \sim N \wedge N$

$n \sim \sim n \sim$

$\sim \sim \sim n \sim$

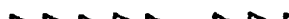

こニュニこ

テテテここ

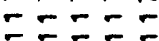

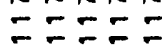

$\check{I} \check{I}$

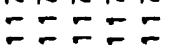

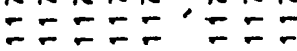

$\propto ⿻ \mathcal{乛} \approx \sim \sim m$

miñng

g도요의

는도

$\simeq \approx \approx \approx \approx$

$\tilde{n} \tilde{m} \tilde{m} \bar{m}=$

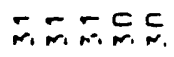

coperis

든윰유

$\stackrel{\sim}{\sim} \sim \underset{\sim}{\sim} \stackrel{\alpha}{\sim}$

ษัก๊ำ

$\tilde{n} \tilde{\sim} \tilde{\sim} \propto \alpha$

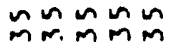

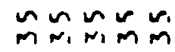

$\sim \tilde{n} \sim \tilde{m} \sim$

r.num

$\sim \tilde{m} \cdot \sim \sim n$

$\approx \sim n \cdot m n$

mํํ윰요 웅

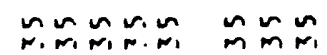




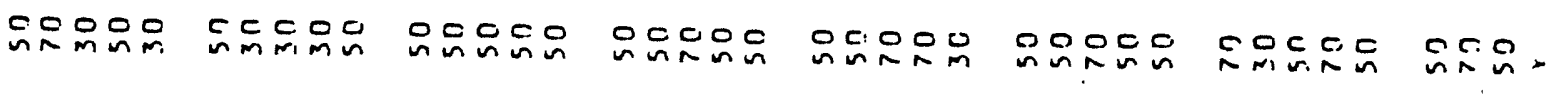

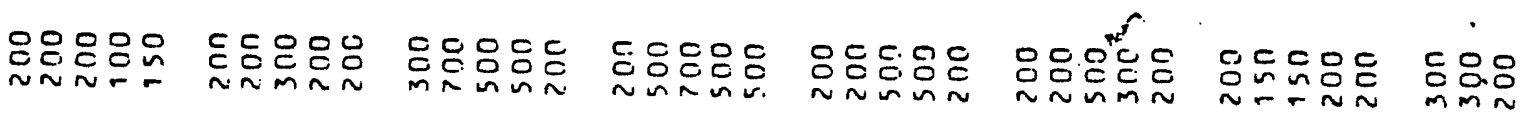

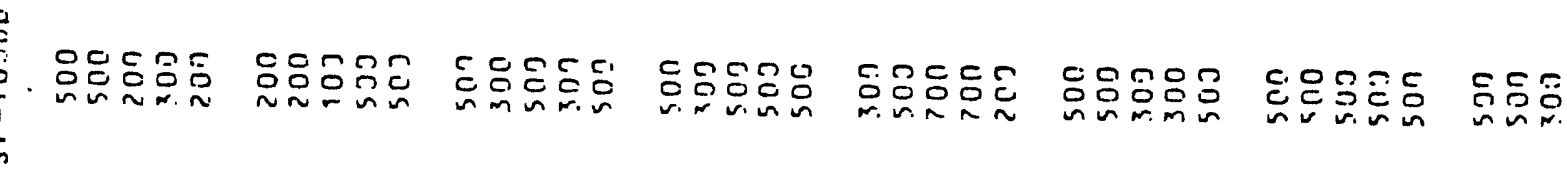

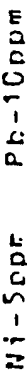

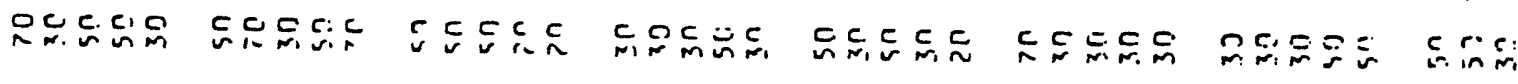

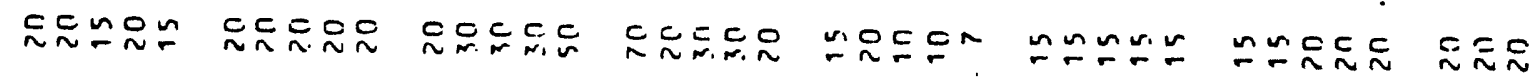

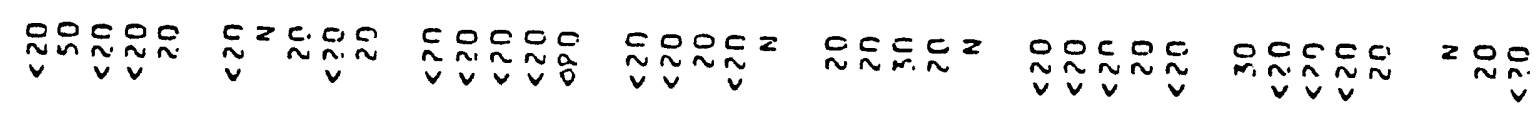

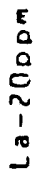

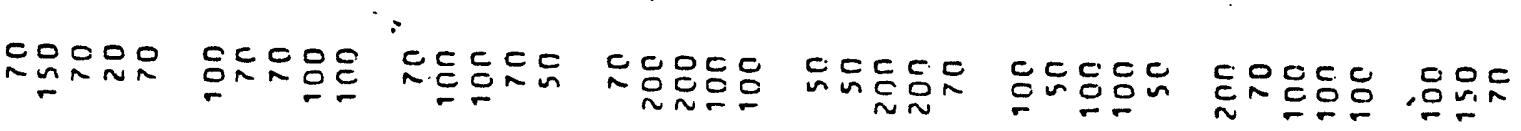

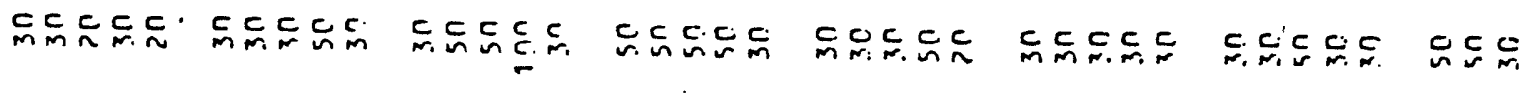




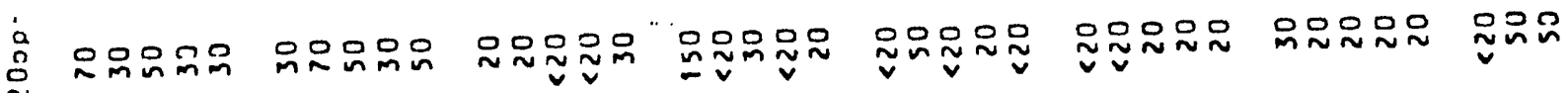

E
O.
0
0

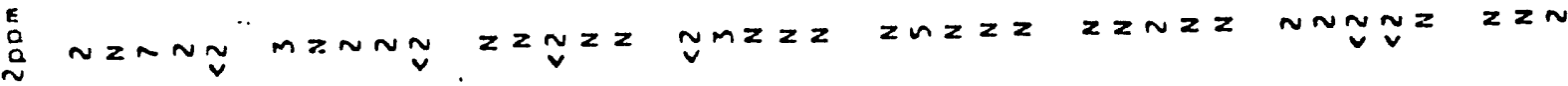

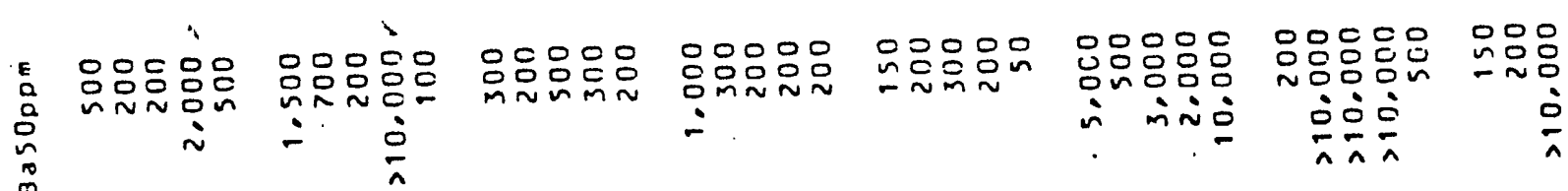

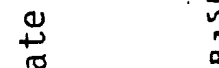

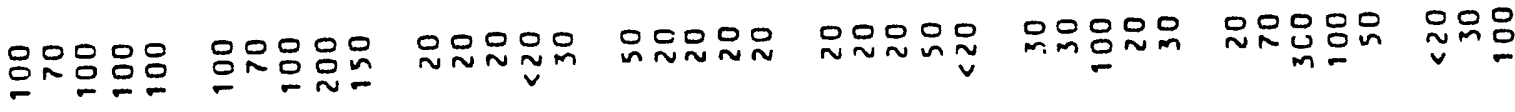

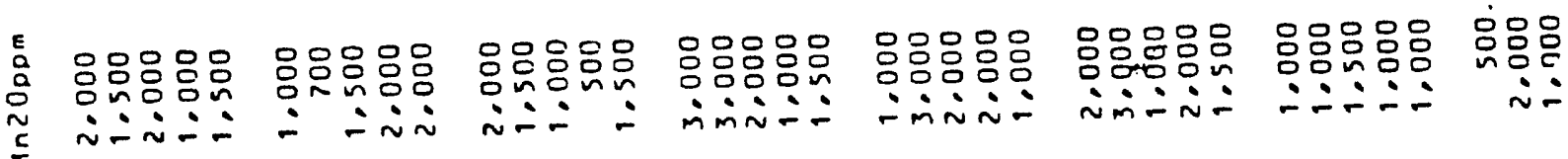

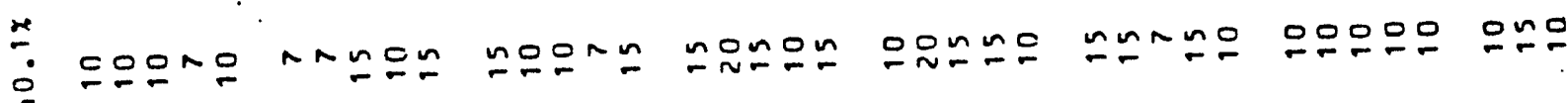

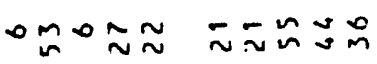

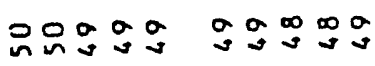

กNNN テニニュニ

กヘกヘ

テニュニュ

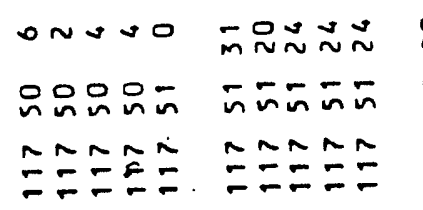

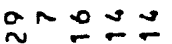

Nmmmm ทักทัก

ニニュニュ ニニニニュ

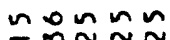

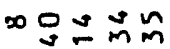
药華宗

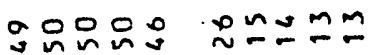
욱움욤요.

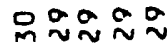
ñกำกำ 的的品品

nnnnnn

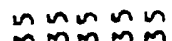
$\stackrel{0}{\sim} \stackrel{\infty}{\sim} \stackrel{\infty}{\sim}$

nnnun

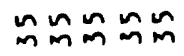

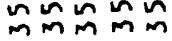

乞

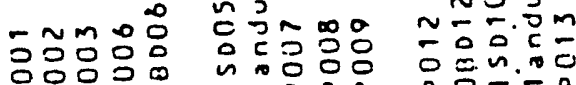
a a a a n voa

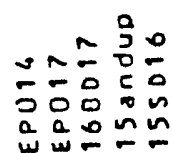

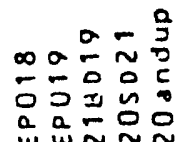

도요 $\sim-\alpha a a$

ヘヘヘNA

ニニニニュ

$\because \tilde{M} \sim \mathcal{N}$ $\approx \approx \approx \infty \infty$ ก ก ก ñnn

ono a g웡의

的立 $00 a$ ลีก̃N ñN モニュニミモミュ

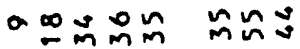
ma交余主

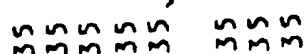

nmano ก $\tilde{N} \tilde{N}$ a 엔 noำ ÑNón a a a 


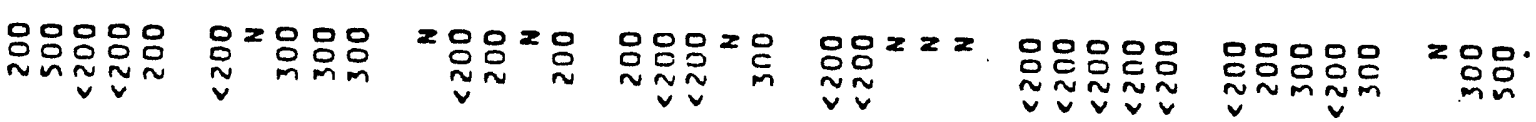

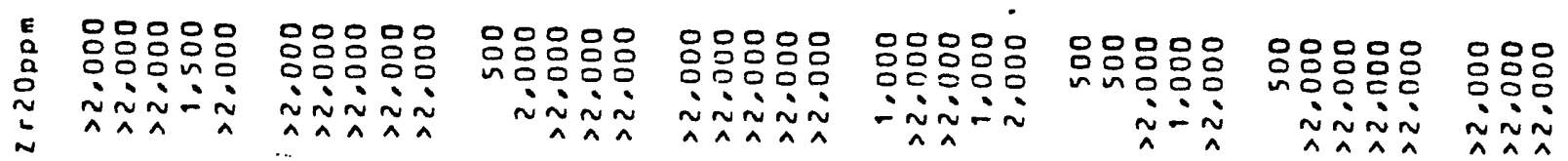

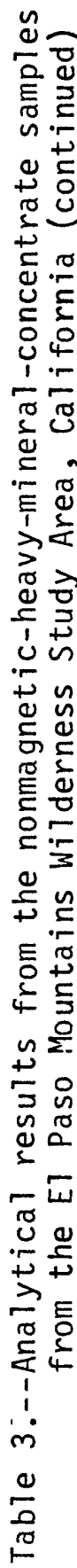

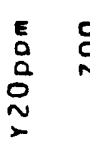

응웅응ㅇㅇㅇㅇㅇㅇ

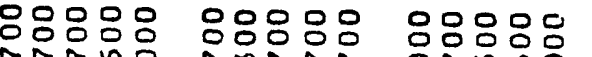

hrung hms

눈ㄷㄴ

응응응음

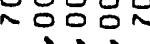

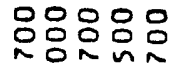

음욤욤유

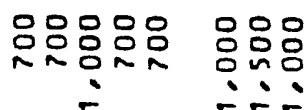

望

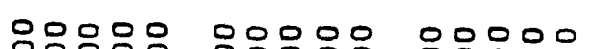

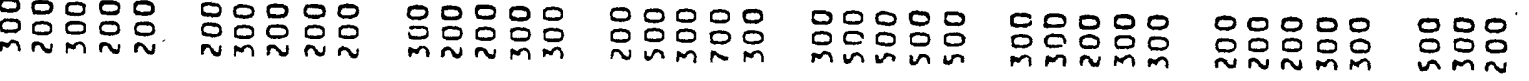

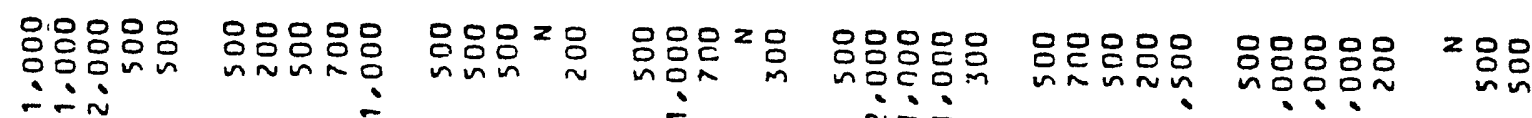
$\therefore \therefore$

inin $\underset{\sim}{0}$

í:

$\therefore \dot{\sim}$

in

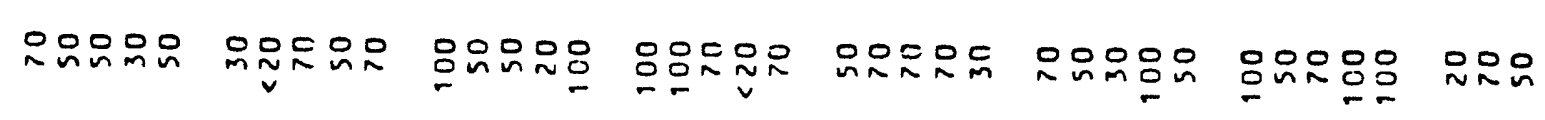

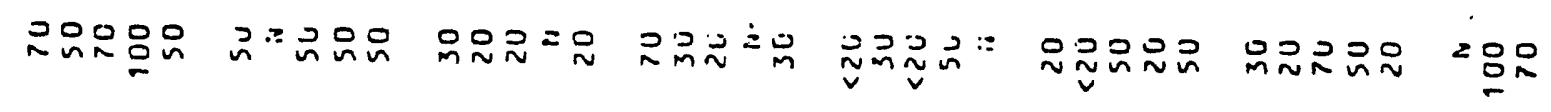

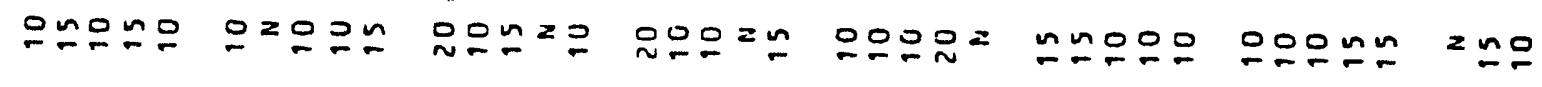

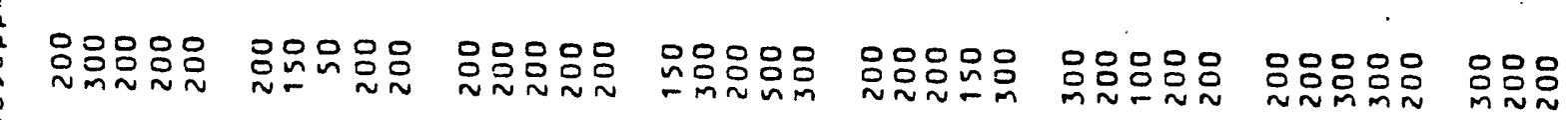

$\underset{\substack{E \\ c}}{\substack{c \\ c}}$

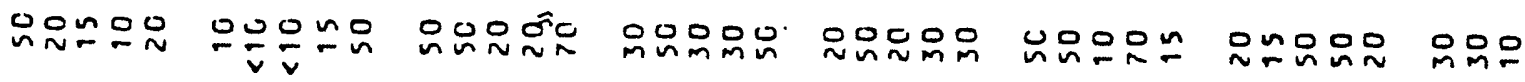

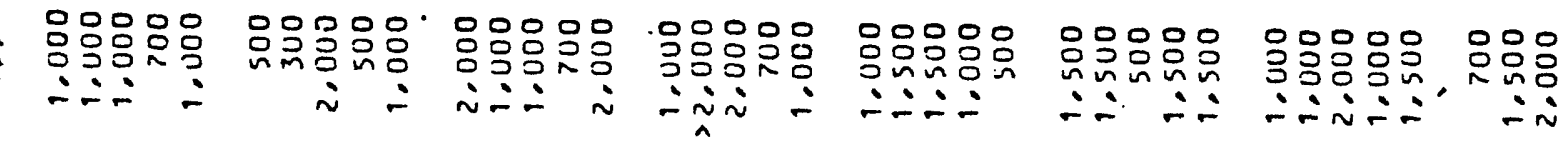

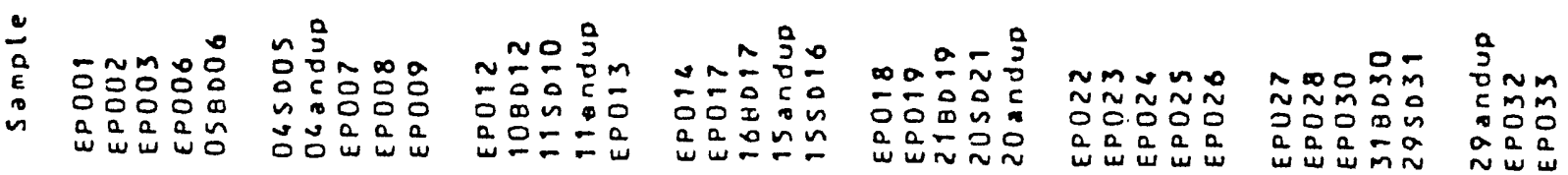

